\title{
Mold Occurrence in Fresh Chilli Pepper (Capsicum spp.) Harvested Directly in the Field in Benin Republic
}

\author{
Nicéphore M. Glodjinon, Msc \\ Pacôme A. Noumavo, PhD \\ Kifouli Adéoti, PhD \\ Hermann Savi, Msc \\ Kamal Garba, PhD \\ Sonangnon S. Kouhoundé, PhD \\ Fatiou Toukourou, PhD
}

Université d'Abomey-Calavi, Laboratoire de Microbiologie et des

Technologies Alimentaires, Bénin

Lamine Baba-Moussa, PhD

Université d'Abomey-Calavi, Laboratoire de Biologie et de Typage

Moléculaire en Microbiologie, Faculté des Sciences et Techniques, Bénin

Aly Savadogo, PhD

Université Ouaga I Pr Joseph Ki-ZERBO, Laboratoire de Biochimie et

Immunologie Appliquée, Burkina Faso

Farid Baba-Moussa, PhD

Université d'Abomey-Calavi, Laboratoire de Microbiologie et des

Technologies Alimentaires, Bénin

\begin{abstract}
Introduction: The chilli pepper (Capsicum spp.), ranked among the world's leading spices or food additives, is now Benin's second most-important vegetable crop after tomatoes. Unfortunately, chilli peppers are likely to be contaminated with mold which produces dangerous mycotoxins due to cultural practices, transport, and post-harvest storage. Objective: The purpose of this study is to isolate and identify the molds that contaminate chilli pepper varieties in open fields according to the cultivation methods used in the Republic of Benin. Materials and Methods: A total of 240 samples of three varieties of chilli peppers were taken directly from six districts of Benin. The molds were isolated and purified on a PDA (Potato Dextrose Agar) medium for identification. The identification focused on the morphological and cultural
\end{abstract}


characteristics of isolated strains. Results: Nine (9) fungal genera from different taxonomic groups were detected. The genera that have been represented are Aspergillus (34\%), Fusarium (21\%), Penicillium (16\%), Alternaria (7\%), Cladosporium (7\%), Mucor (7\%), Scytalidium (4\%), Trichophyton (3\%), and Rhizopus (1\%). Conclusion: The present study shows that chilli pepper is being contaminated in Benin. The genera Aspergillus, Fusarium, Penicillium, and Alternaria are respectively the main toxinogenic molds that contaminate peppers in the field. The mold control in chilli pepper against pathogenic agents became urgently required to reduce a consumer disease caused by chilli pepper in Benin.

Keywords: Benin, Chilli Pepper, Molds, Mycotoxins, Occurrence

\section{Introduction}

Around the world, chilli pepper is classified among the leading spices or food additives. The chilli pepper (Capsicum spp.) is now the second in market garden crops after tomatoes in Benin (INRAB, 2009). It is rich in vitamins (A, B6, C, E, K); in trace elements such as copper, iron, manganese, and potassium; and also in ascorbic acid, flavonoids, oligosaccharides, and carotenoid compounds (Orobiyi, 2015). In Benin, chilli pepper is one of the most produced and consumed vegetable crops undeniably occupying a prominent place in the Beninese household. Several varieties of chilli pepper are used in fresh fruit directly from the fields, in dried fruit from the conservation, and transformed into paste or powder for the preparation of different foods. In addition to food, chilli pepper is also used for its medicinal properties (FAO, 2016). In phyto-medicine, the fruit is used orally as an infusion to improve blood circulation, treat nausea, high blood pressure, diabetes, and overweight (Lejeune et al., 2003; Koffi et al., 2014). The main interest of chilli pepper is in its physicochemical composition (Tilahun et al., 2013) which varies according to its varieties and environmental conditions (Bae et al., 2012; Toffa, 2015). Its richness in antioxidants among which capsaicin is found gives it a great nutraceutical value (nutritional and medicinal). Unfortunately, the presence of fungal contaminants on chilli pepper varieties is effective. Chilli pepper is likely to be contaminated with Xerophilous xerophilic toxigenic fungi in the field, after harvest, during transport, and during storage (FAO/WHO, 2017). Indeed, the cultural practices used could have a significant impact on the chilli pepper contamination in the field, especially in the humid lowlands. Also, the improper storage or preservation methods used and the unsuitability of certain varieties for conservation would also lead to attacks by micro-organisms including molds of the genus Aspergillus, Penicillium, Fusarium, and Alternaria, etc. (Zinedine, 2004; Nguyen, 2007; Debodé et al., 2016). They 
are heterotrophic eukaryotic unicellular or multicellular fungi of complex structure, endowed with the power of sporulation, which grow on the surface of foodstuffs because of their aerobic nature (Toffa, 2015; Meilé, 2017). They are the most known contaminants of chilli pepper. Once on the chilli pepper, these micro-organisms alter their sanitary quality causing, thus, enormous economic losses (INRAB, 2009; Fondio et al., 2015). Generally, contamination evolves after harvest, storage, or storage based on a combination of intrinsic and extrinsic factors (Royer \& Tap, 2004; Toffa, 2015). There is no doubt that molds have a remarkable ability to adapt. Therefore, a change in a technological process can lead to a quantitative and qualitative change in mycoflora. A large number of mold species belonging mainly to the three very common genera, Aspergillus, Penicillium, and Fusarium (Zinedine 2004; Nguyen, 2007; Debodé et al., 2016), present in ambient air and soil, of agricultural crops are able, for example, to develop on certain substrates such as peanuts, spices, coffee, and cereals to synthesize and excrete mycotoxins (Garba et al., 2014; Ba et al., 2016; Tovidé et al., 2018). Basically, these are products of their secondary metabolism, and they are very toxic for humans and animals (Tozlovanu, 2008; Toffa, 2015; Debodé et al., 2016; Meilé, 2017). Productive mold may also disappear from the food, while mycotoxins, which are very stable, may persist even after heat treatment (Toffa, 2015; Debodé et al., 2016). Therefore, a better knowledge of chilli pepper infective mold in Benin and mycotoxin production potential of mold strains will facilitate better risk prediction and corrective measures in Hazard Analysis Critical Control Point (HACCP) system. Therefore, the objective of this work is to study the variability of the contaminating molds of chillies according to the technical production, storage, or conservation routes.

\section{Material and Methods}

\subsection{Sampling}

The chilli peppers were sampled in southern Benin in the district of Ouémé, Plateau, Zou, Collines, Atlantique, and Littoral (Figure 1). The three main varieties most produced and consumed in Benin were the subject of this study. These varieties are: variety of round form called Gbotakin in the local language of Fon (Capsicum chinense), long-sized variety called Afundja in the local language of Fon (Capsicum annuum), and the very small variety called Danhometakin in the local language of Fon (Capsicum frutescens) (Photo 1). A total of 240 samples of three varieties of chilli peppers were collected directly in the communes of the six districts mentioned. 


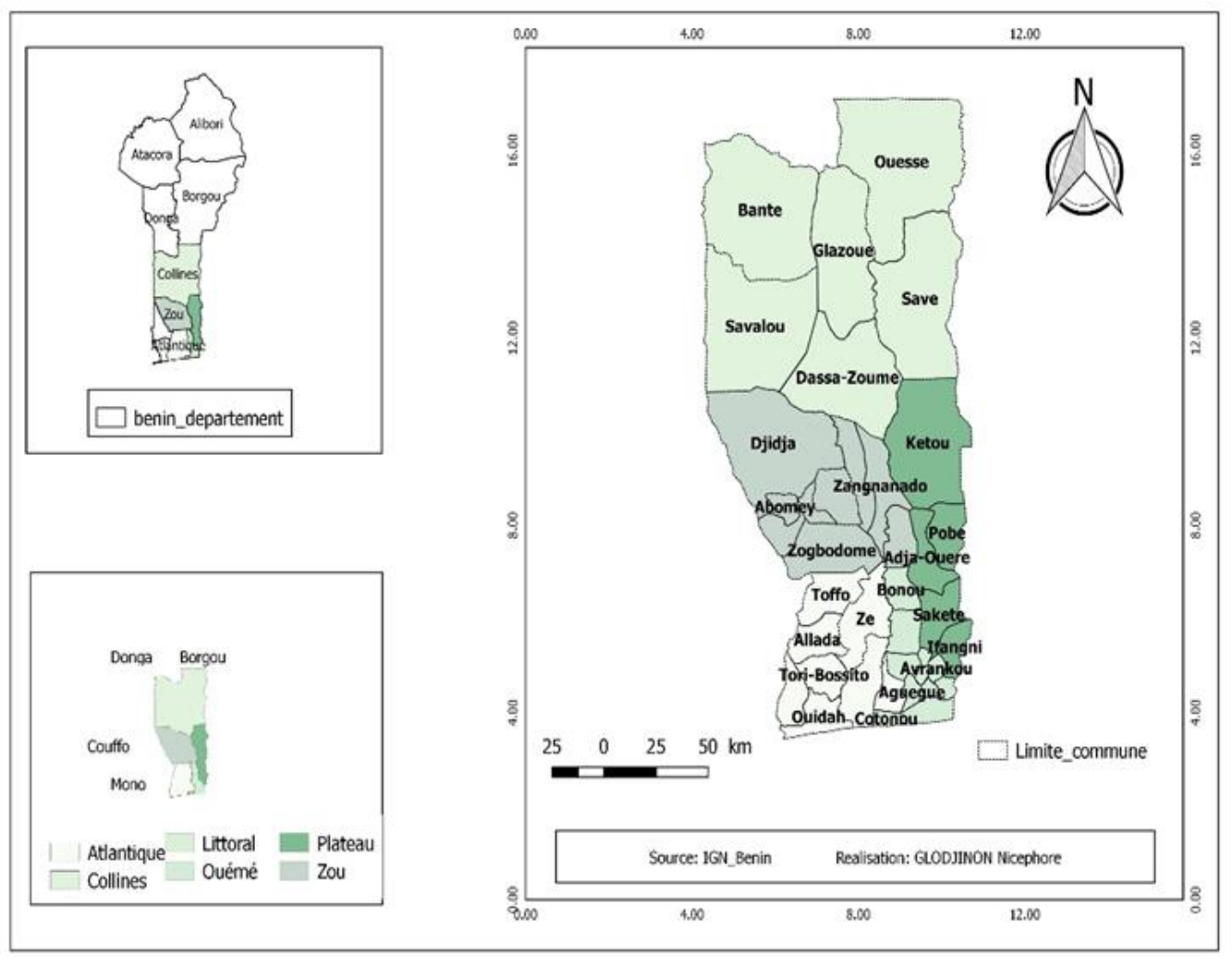

Figure 1. Figure showing the location of communes surveyed by district

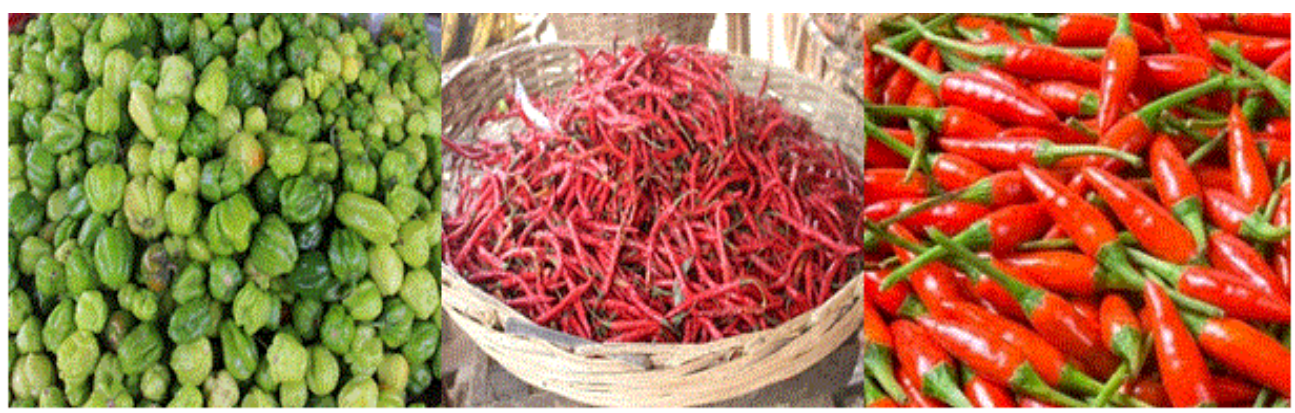

Photo 1. Chilli pepper varieties used in this study.

[A] Fresh Gbotakin variety, [B] Fresh Afundja variety, [C] fresh Danhometakin variety.

\subsection{Enumeration of Aerobic Total Mesophilic Flora}

The total mesophilic aerobic flora was counted by the bulk inoculation technique on Plate Count Agar (PCA) culture medium from the decimal dilutions $\left(10^{-5}, 10^{-6}\right.$, and $\left.10^{-7}\right)$ prepared. This was done by adding $10 \mathrm{~g}$ of sample to $90 \mathrm{ml}$ of a $0.1 \%$ sterile buffered peptone water solution. Then, $1 \mathrm{ml}$ of each dilution was put into two boxes kneaded by dilution. Since the inoculum was already in the dishes, about $15 \mathrm{ml}$ of the super-cooled culture 
medium was then poured and the whole was then incubated at $30^{\circ} \mathrm{C}$ for 72 hours after solidification. After culture, only boxes with a colony count between 30 and 300 were taken into account for the different statistical analysis.

\subsection{Enumeration of Molds}

Dilutions $10^{-1}, 10^{-2}$, and $10^{-3}$ were prepared by adding $10 \mathrm{~g}$ of sample to $90 \mathrm{ml}$ of a sterile $0.1 \%$ peptone water solution. Then, $0.1 \mathrm{ml}$ of each dilution was inoculated on Sabouraud surface with Chloramphenicol at the rate of two Petri dishes by dilution and then incubated at $25^{\circ} \mathrm{C}$. Counting was performed from the third day of incubation by evaluating the number of colony-forming units per gram of chilli pepper (CFU/g) for 5 days.

\subsection{Characterization of Molds}

\subsubsection{Isolation, Purification, and Conservation of Strains}

From colonies obtained on Sabouraud agar Chloramphenicol, those with mold features were separated by isolation. The latter were placed directly on a standard selective medium such as Chloramphenicol PDA (Potato Dextrose Agar) agar and the petri dishes were incubated at $25^{\circ} \mathrm{C}$ for 7 days. The strains formed were isolated again and then purified according to the technique of successive subcultures in peak by exhaustion of fungi. The last colonies pushed on the successive subculturing points by exhaustion constituted the pure strains. The pure strains obtained were stored in buffered peptone water at $4^{\circ} \mathrm{C}$ for later identification.

\subsubsection{Morphological Identification of Isolated Strains}

The morphological identification of mold strains was based on the cultural characteristics and the morphology of fructifications and spores. Also, the identification keys used were those of Raper and Fennell (1965) and Pitt and Hocking (1985) recently described and reported with some modifications by Campbell et al. (2013) and Dufresne and St Germain (2018). These methods have been used by several authors for the morphological (macroscopic and microscopic) identification of molds of the genus Aspergillus, Penicillium, Fusarium, and thermophilic filamentous fungi (Cooney \& Emerson, 1964; Chabasse et al., 2002; Lecellier, 2013; Houmairi \& Hicham, 2015; Compaore et al., 2017).

\subsubsection{Macroscopic Characteristics}

The macroscopic characteristics of isolated and purified mold strains on PDA and MEA agar were determined with the naked eye with cultures of at least 7 days incubated at $25^{\circ} \mathrm{C}$. This is mainly the shape, size, color, appearance, contour, and growth rate (fast, medium, slow) of fungal colonies. 


\subsubsection{Microscopic Identification}

The superficial part of the fungal mycelium was removed with a sterile platinum loop and placed on a slide to which lactophenol blue was added as a diluent. The characteristics noted were: the color, appearance and size of conidiophores, the number of conidia, the shape of the head (aspergillary, penicillary, and fusariare), differentiation of thallospores, mode of branching of septa, and the presence of metulae. The observation was made with the Optical Microscope-LCD Digital coupled to a camera for the capture of images. Magnifications $(\times 10)(\times 40)$ and immersion magnification $(\times 100)$ were used.

\subsection{Statistical Analysis}

The data collected from the results of manipulations on the collected samples were captured using the Excel 2016 software. The results of the enumeration of the aerobic total mesophilic flora (TAMF) and that of the yeasts and molds (YM) were submitted to the LSD-Test (Fisher's Least Significant Difference-Test) and the Student-Newman-Keuls test using Statistical Analysis System (SAS) version 8.1. This was performed in order to compare the averages between the contamination loads of the studied peppers and to determine the significant differences between the means of the districts. The difference was considered statistically significant when the value of $\mathrm{p}<$ 0.05. The geographical map of the sampling zones was carried out using Qgis software version 2.14 .

\section{Results}

\subsection{Global Contamination of Chilli Peppers Studied by Microorganisms}

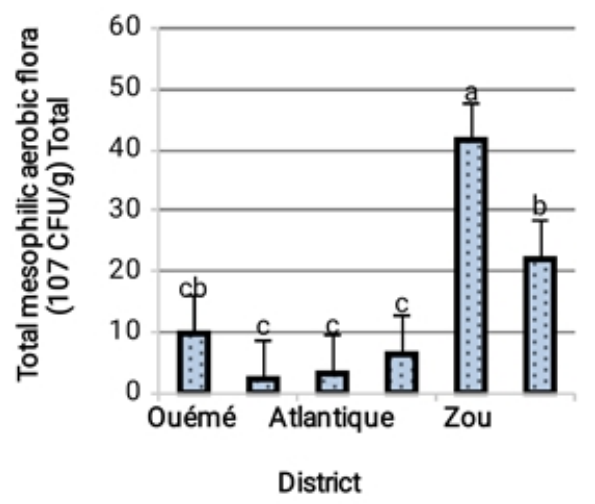

Figure 2. Microbial load in total mesophilic and molds (YM)

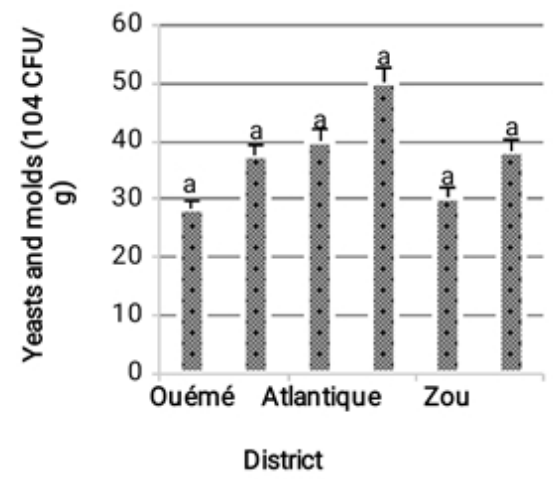

Figure 3. Microbial load in yeasts aerobic flora (TAMF) 


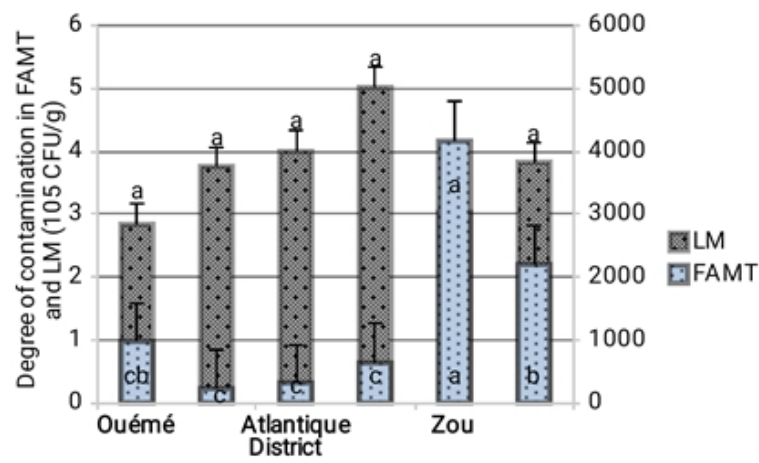

Figure 4. Degree of contamination in TAMF and YM of studied chilli peppers

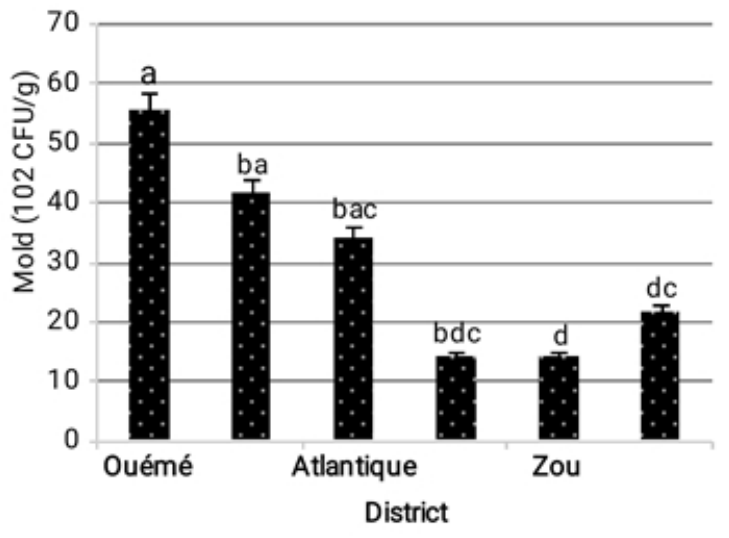

Figure 5. Microbial load in mold of studied chilli peppers

The means between districts with the same letters are not significantly different at the $5 \%$ probability level according to Fisher's LSD test and $=p>0.05$ (no difference); $*=p<0.05$ (significant); $* *=\mathrm{p}<0.01$ (highly significant); $* * *=\mathrm{p}<0.001$ (very highly significant).

\subsection{Morphological Characterization of Isolated Strains}

Purified molds were identified by macroscopic examination that was performed after incubation for at least 7 days on PDA medium with choramphenicol at a temperature of $25^{\circ} \mathrm{C}$, and slide microscopic examination with lactophenol added as diluent, gives results which have been mentioned below (Table 1).

A total of seventy-six (76) mold strains were isolated, purified, and characterized from 240 chilli pepper samples. Thus, Table 1 summarizes the appearance of the mycelium of some isolated fungal strains, the consistency of the colonies, the color of the back of the box, and the presence or absence of pigments characteristic of each strain. Table 2 presents the representative descriptive characteristics of each of the isolated fungal genera and their reference images. 
Table 1. Macroscopic and microscopic characteristic $\left(\mathrm{G} \mathrm{X} \mathrm{40)}\right.$ of the molds grew at $25^{\circ} \mathrm{C}$ on PDA medium

\begin{tabular}{|c|c|c|c|c|}
\hline CODES & $\begin{array}{c}\text { MACROSCOPIC OBSERVATION } \\
\text { (BOTH \& SIDES) }\end{array}$ & MICROSCOPIC OBSERVATION & $\begin{array}{c}\text { CHARACTERISTICS } \\
\text { SPECIES }\end{array}$ & $\begin{array}{l}\text { FUNGAL } \\
\text { GENERA }\end{array}$ \\
\hline M9R3 & & 6 & $\begin{array}{l}\text { *Color } \\
\text {-revers: Beige } \\
\text {-mycelium: white } \\
\text {-spores: Yellowish green } \\
* \text { diameter: } 4 \mathrm{~cm} \\
* \text { growth: rapid } \\
* \text { appearance : powdery }\end{array}$ & Aspergillus sp. \\
\hline M109R1 & & & $\begin{array}{l}\text { *Color } \\
\text {-revers: yellow rack } \\
\text {-mycelium: white } \\
\text {-spores: black } \\
* \text { diameter: } 5 \mathrm{~cm} \\
* \text { growth: rapid } \\
\text { * appearance: granular } \\
\text { and floury }\end{array}$ & Aspergillus sp. \\
\hline
\end{tabular}


M46R3
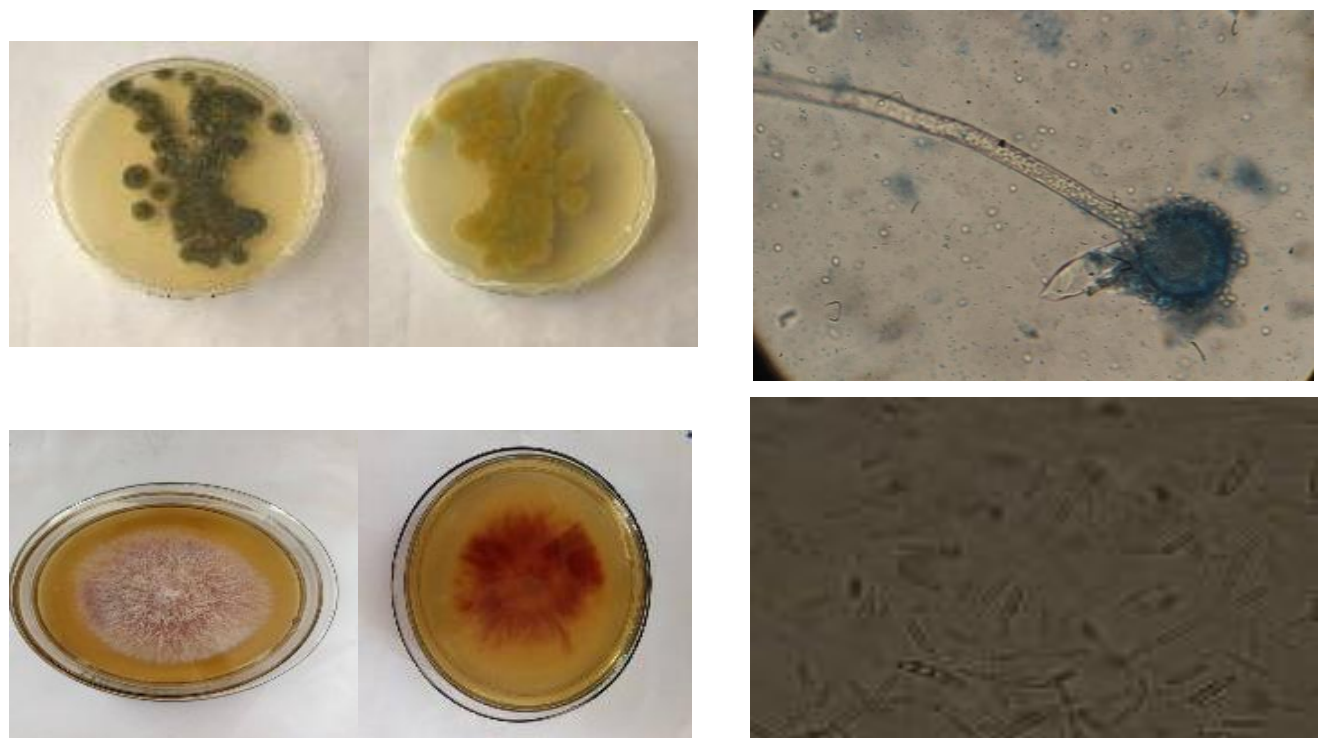

M38R3

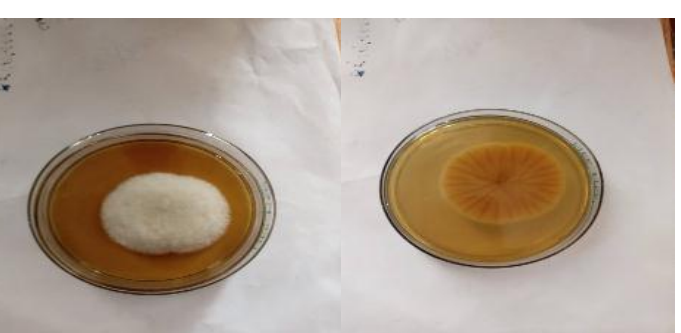

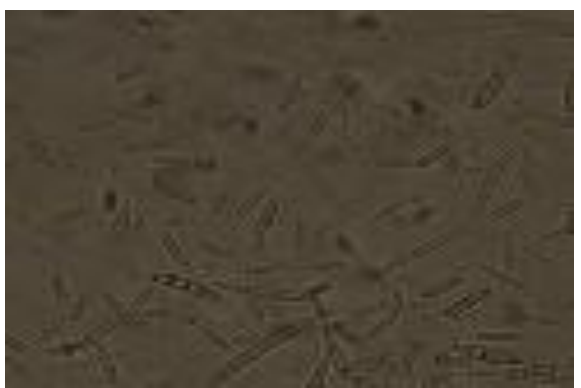

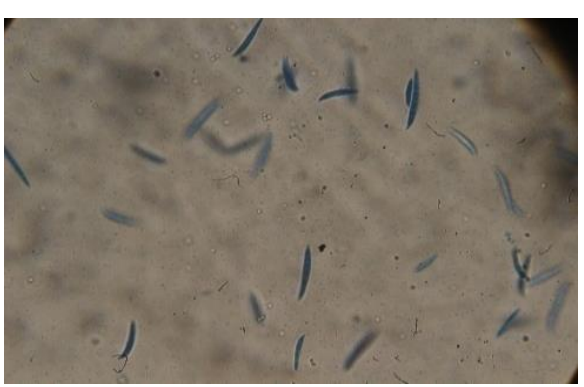

*Color

-revers: beige

-mycelium: green

-spores: green

* diameter: $1,2 \mathrm{~cm}$

* growth: rapid

* appearance: powdery

\section{*Color}

-revers: mustard yellow -mycelium: light pink -spores: light pink

* diameter: $7.1 \mathrm{~cm}$

* growth: rapid

* appearance : ovoid and cottony

\section{*Color}

-revers: pure beige

-mycelium: white

-spores: white

* diameter: $5.5 \mathrm{~cm}$

-growth: average

* appearance: cottony
Aspergillus

sp.

Fusarium sp.

Fusarium sp. 
M26R5
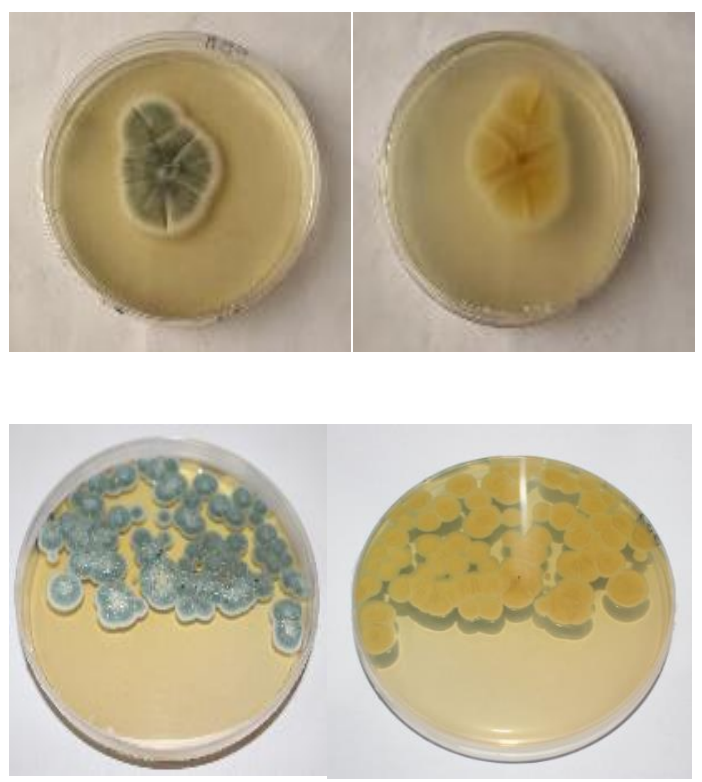

M1R3

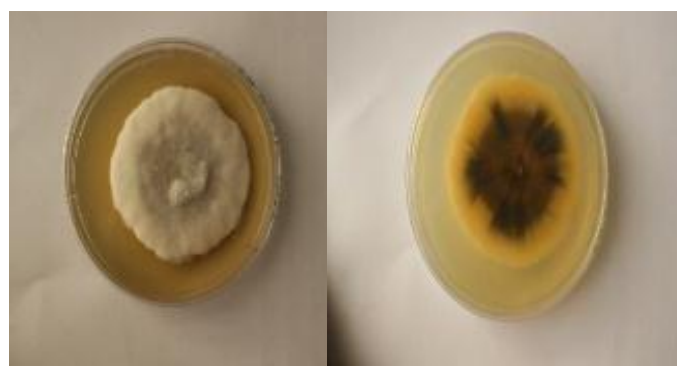

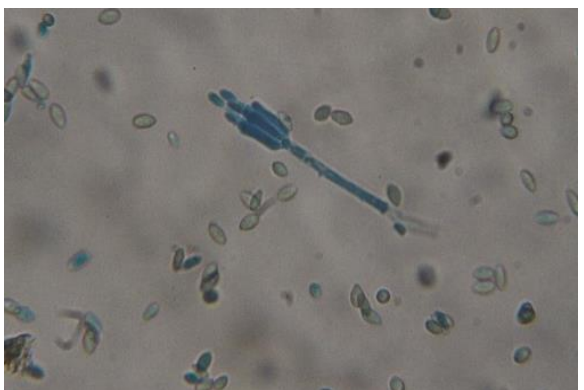
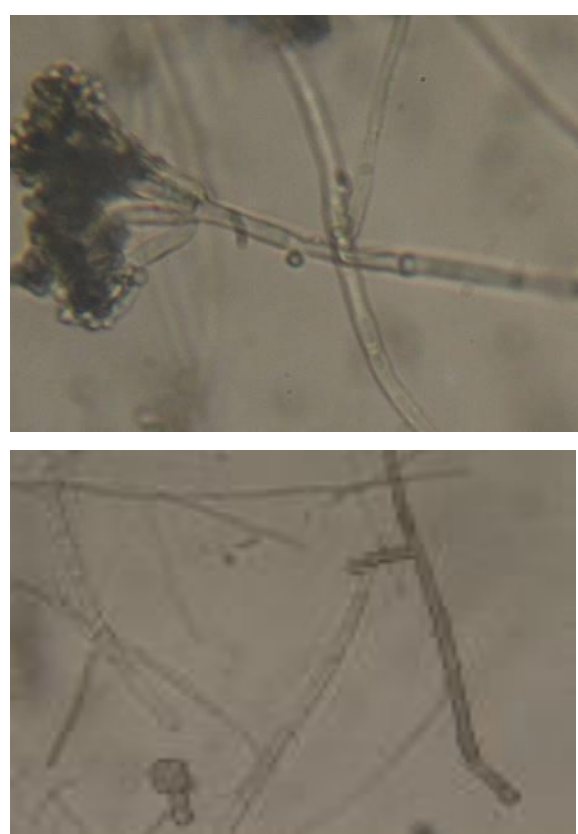

*Color

-revers: yellow

-mycelium: white

-spores: White, green

* diameter: $3.7 \mathrm{~cm}$

* growth: average

* aspect: Wool

*Color

-revers: Yellow

-mycelium: Green

-spores: green

* diameter: 1, $2 \mathrm{~cm}$

* growth: rapid

* appearance : powdery and invasive

*Color

-revers: Beige, black

-mycelium: white

-spores: White

* diameter: $5,8 \mathrm{~cm}$

* growth: rapid

* appearance: cottony
Penicillium

sp.

Pénicillium sp.

Alternaria sp. 
M59R4
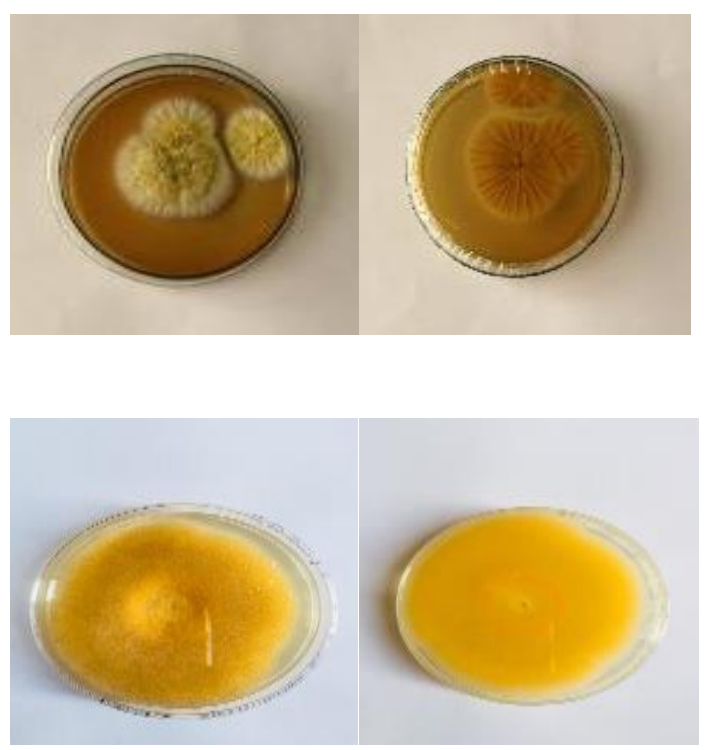

M125R4

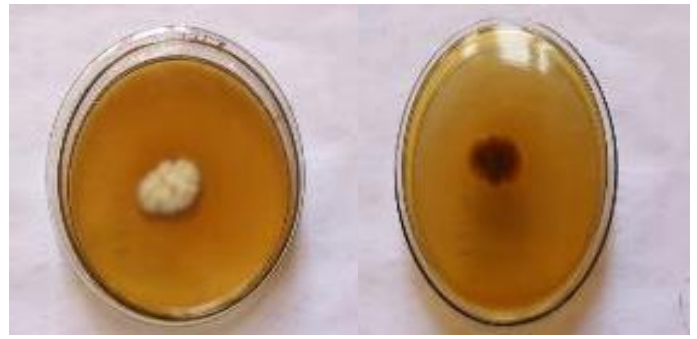

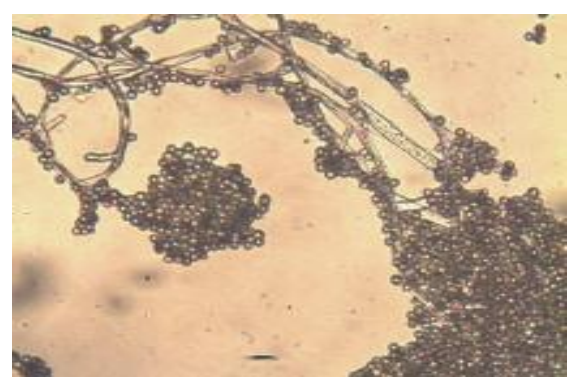
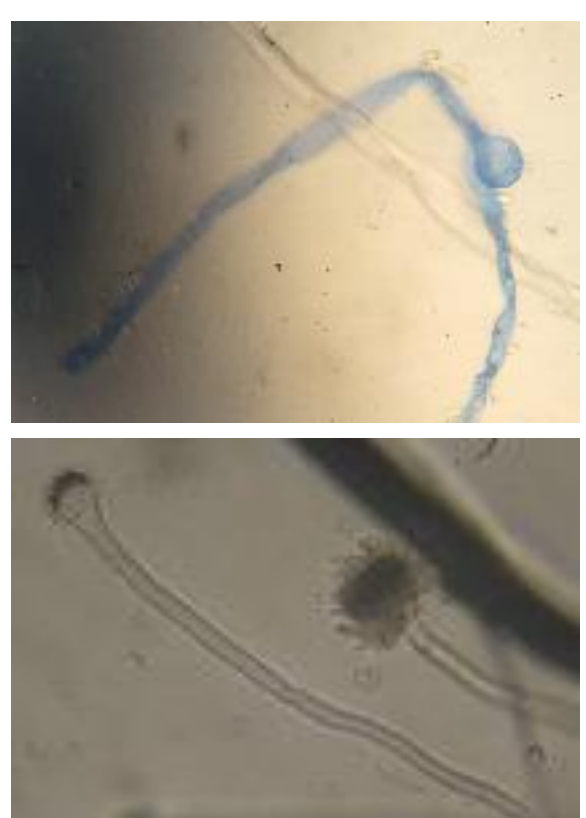

\section{*Color}

-revers: Beige

-mycelium: White

-spores: Yellow

* diameter: $2,3 \mathrm{~cm}$

* growth: Average

* appearance: Cottony and powdery

\section{*Color}

-revers: yellow -mycelium: yellow

-spores: yellow

* diameter: $8.2 \mathrm{~cm}$

* growth: rapid

* appearance : Cottony

\section{*Color}

-revers: Black

-mycelium: white

-spores: white

* diameter: $1 \mathrm{~cm}$

* growth: slow

* appearance: cottony and pleated

\section{Cladosporium sp.}

Mucorsp.

\section{Mucor sp.}


M29R5
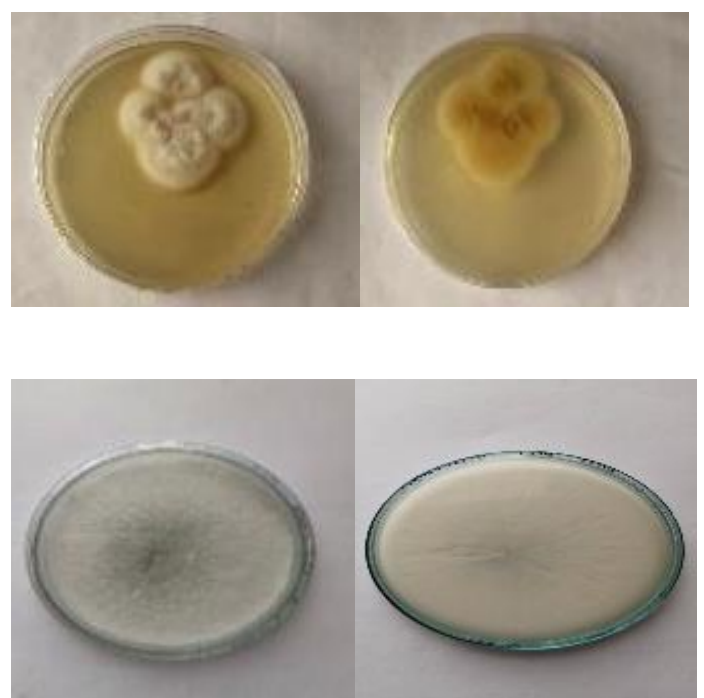

M122R1

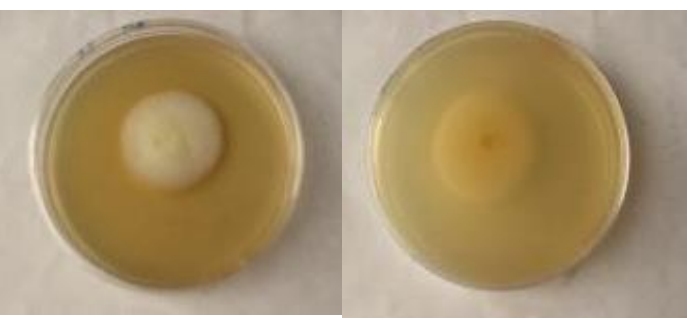

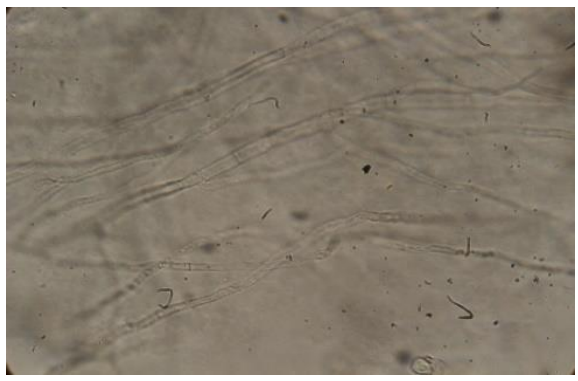
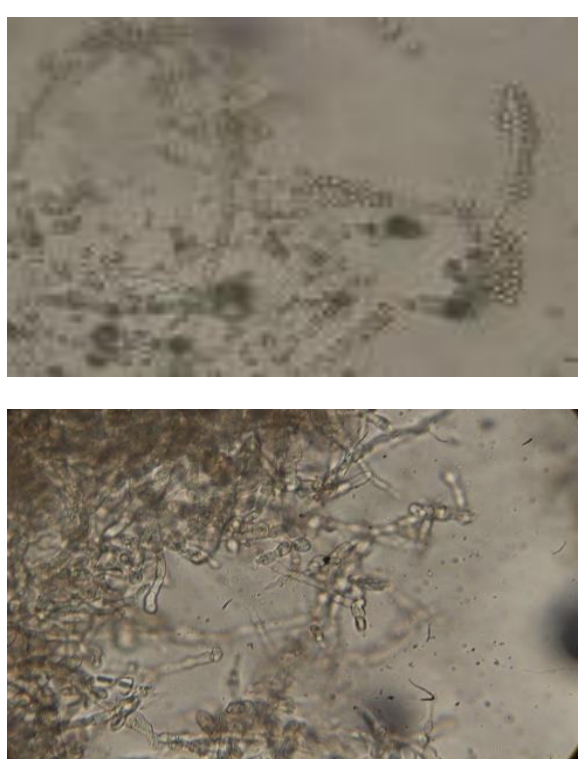

*Color

-revers: yellow

-mycelium: White

-spores: Beige

* diameter: $2,9 \mathrm{~cm}$

* growth: average

* appearance: Cottony

*Color

-revers: White

-mycelium: white

-spores: white

* diameter: $8,4 \mathrm{~cm}$

* growth: rapid

* appearance : cottony

*Color

-revers: Beige

-mycelium: White

-spores: beige

* diameter: $3.9 \mathrm{~cm}$

* growth: average

* appearance: ovoid and cottony
Scytalidium

sp.

Trichophyton sp.

Rhizopus sp. 
Table 2. References of isolated fungal genera

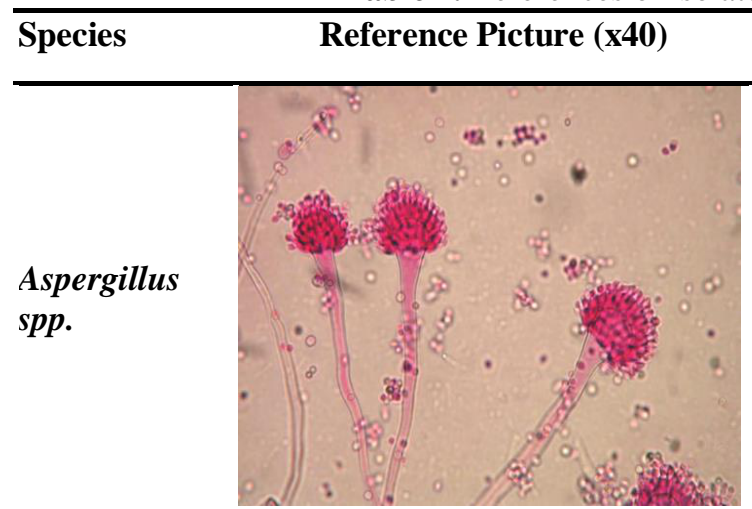

\section{Descriptive Characteristics}

Demonstration of aspergillary heads on microscopic examination of colonies.

A vegetative thallus formed of hyaline filaments, of fine and regular diameter, septate and branched.

(Campbell et al., 2013)

Fusarium spp.

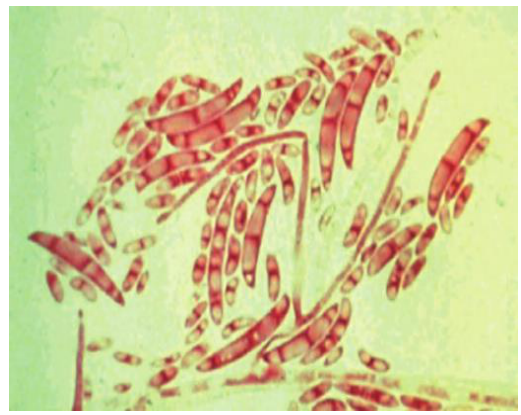

Conidiophores short and often branched. They carry phialides that may have one or more budding sites for the production of conidia.

(Campbell et al., 2013)

Pénicillium

spp.
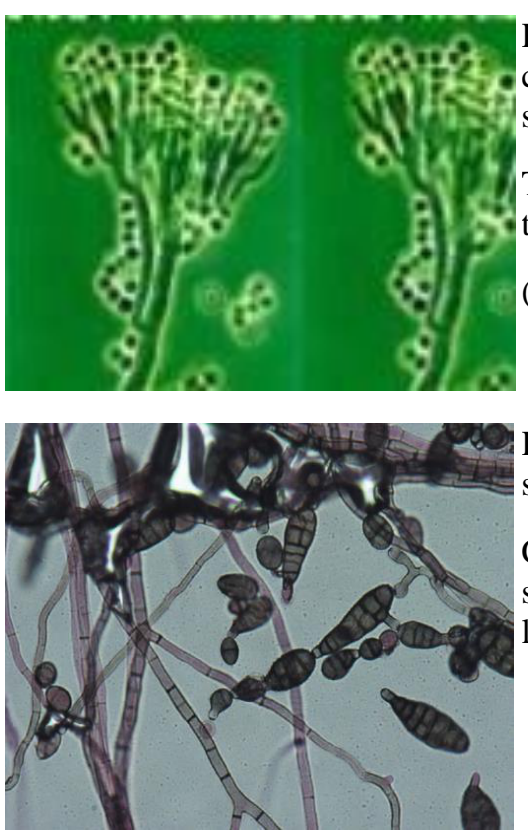

Hyphae septa, hyaline, bear conidiophores simple or branched, are sometimes grouped in bush or coremia.

The phialides are arranged in whorls at the end of the conidiophores.

(Campbell et al., 2013)

Alternaria spp.

Hyphae, septate, are branched and later some filaments are pigmented brown.

Conidiophores are septate, brown, septate, simple or branched, more or less straight or flexuous (geniculate).

(Dufresne \& St Germain, 2018) 
Cladosporium spp.

\section{Mucor spp.}

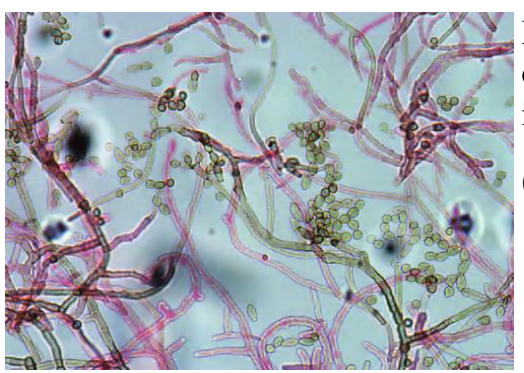

Hyphae, septate, are pigmented. Plain or multicellular blastospores arranged in acropetal chains.

(Campbell et al., 2013)

Cloisonne filaments, globular sporocyst, round spores.

Broad filaments little gold no septate.

No stolons nor rhizoids.
Scytalidium

spp.

\section{Trichophyton}

spp.

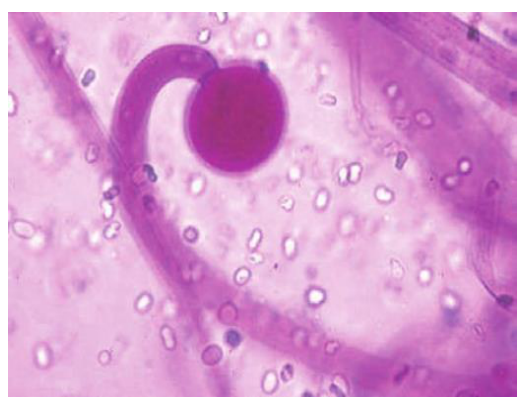

(Campbell et al., 2013)

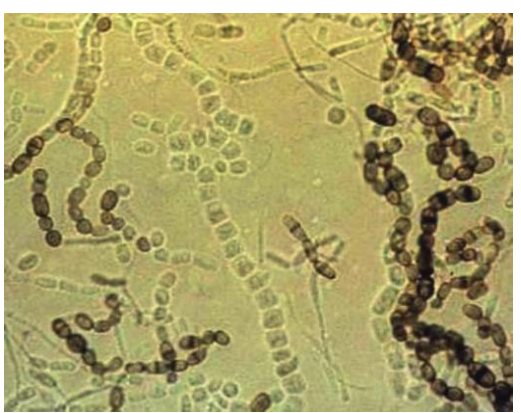

The hyphae are regular, septate, and hyaline.

(Chabasse et al., 2002)

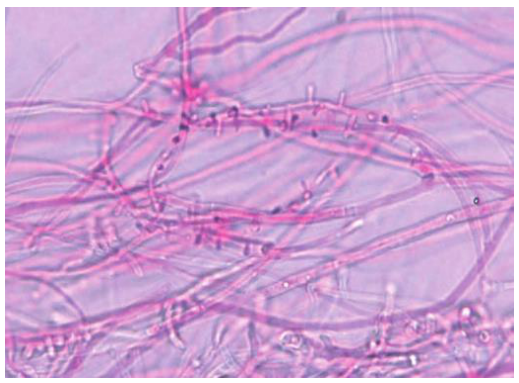

Macroconidia absent;

Microconidia club-shaped, formed along the sides of the hyphae.

(Dufresne \& St Germain, 2018) 
Rhizopus spp.

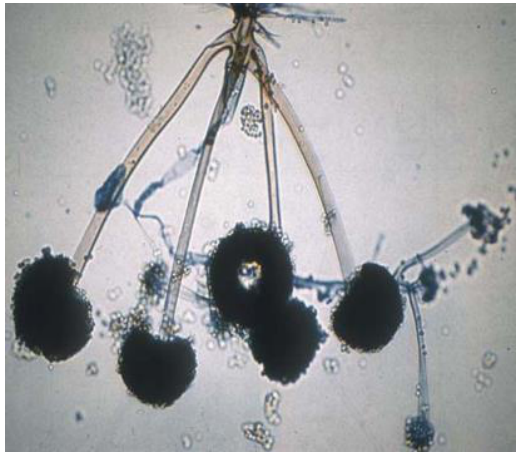

Mushroom with non-septate filaments.

Wide filaments not or slightly septate.

Stolons, rhizoids and sporocystophores are well differentiated. The spores are ovoid.

(ANOFEL, 2014)

Table 3. Relative number and frequency of isolated and characterized mold species on the chilli peppers studied.

\begin{tabular}{|c|c|c|c|}
\hline Fungal species & Number & Frequency & Mold species \\
\hline Aspergillus spp. & 26 & $34 \%$ & $\begin{array}{l}\text { Aspergillus niger } \\
\text { Aspergillus flavus } \\
\text { Aspergillus } \\
\text { ochraceus } \\
\text { Aspergillus } \\
\text { parasiticus } \\
\text { Aspergillus fumigatus } \\
\text { Aspergillus nidulans } \\
\text { Aspergillus flavipes } \\
\text { Aspergillus oryzae } \\
\text { Aspergillus spp. }\end{array}$ \\
\hline Fusarium spp. & 16 & $21 \%$ & $\begin{array}{l}\text { Fusarium solani } \\
\text { Fusarium } \\
\text { moniliforme } \\
\text { Fusarium oxysporum } \\
\text { Fusarium } \\
\text { proliferatum } \\
\text { Fusarium spp. }\end{array}$ \\
\hline Pénicillium spp. & 12 & $16 \%$ & $\begin{array}{l}\text { Pénicillium expansum } \\
\text { Pénicillium } \\
\text { cyclopium } \\
\text { Pénicillium citrinum } \\
\text { Pénicillium notatum } \\
\text { Pénicillium } \\
\text { citreonigrum } \\
\text { Pénicillium spp. }\end{array}$ \\
\hline Alternaria spp. & 5 & $7 \%$ & $\begin{array}{l}\text { Alternaria alternata } \\
\text { Alternaria infectoria } \\
\text { Alternaria spp. }\end{array}$ \\
\hline
\end{tabular}

Cladosporium

spp.
5

$7 \%$

Cladosporium spp. 


\begin{tabular}{lccl} 
Mucor spp. & 5 & $7 \%$ & $\begin{array}{l}\text { Mucor spp. } \\
\text { Trichophyton spp. }\end{array}$ \\
$\begin{array}{l}\text { Scyatalidium spp. } \\
\text { Schophyton spp. }\end{array}$ & 2 & $4 \%$ & $\begin{array}{l}\text { Scytalidium } \\
\text { dimidiatum } \\
\text { Scyatalidium spp. } \\
\text { Rhizopus spp. }\end{array}$ \\
Rhizopus spp. & 1 & $1 \%$ & - \\
\hline Total number : & 76 & $100 \%$ & \\
\hline
\end{tabular}

\section{Discussion}

The level of contamination of chilli peppers by the aerobic total mesophilic flora, yeasts, and molds are presented in Figures 2 and 3. According to these results, it can be seen that $34 \%$ of the chilli peppers studied, all origins combined, have a mean microbial load in aerobic mesophilic flora. It is quite high and is above the threshold recommended by the Quebec standard $\left(10^{8} \mathrm{CFU} / \mathrm{g}\right)$ (CQIASA, 2009) with a maximum microbial load of 4.93.10 ${ }^{8} \mathrm{CFU} / \mathrm{g}$. It also emerges from these results that there is a high significance at the 5\% threshold between the samples coming from the same district and between certain district in a specific way. Thus, between the district of Zou and that of the hills, there is a highly significant difference in the aerobic total mesophilic flora. Also, there is also a highly significant difference between these two districts and those of the Littoral, Atlantic, and Plateau between where there is no differentiating significance.

Yeasts and molds are also above the recommended threshold $\left(10^{5}\right.$ CFU/g) for spices, fresh fruits, and vegetables by the Quebec standard (CQIASA, 2009) for all samples of chilli peppers studied. It should be noted that there is no significant difference at the level of 5\% threshold between samples analyzed from the same district and from the six districts for yeast and mold. Of the samples analyzed, Figure 4 shows that all districts are more contaminated by yeasts and molds with the exception of Zou district which is more contaminated by aerobic total mesophilic flora. These values are similar and consistent with those reported by Kumar et al. (2008) and Fondio et al. (2015) who have shown that the microorganisms that contaminated chilli pepper varieties are more fungi, including yeasts and especially molds, than bacteria.

Figure 5 shows the molds contamination of chilli peppers studied. These results show that the district of Ouémé is the most contaminated area by the mold. Opposite to Ouémé, the district of Zou is the least contaminated. Also, there is a very high significance at the 5\% threshold for the six study districts with regard to the mold species contaminating the chilli peppers studied. This high level of mold contamination observed in the district of Ouémé is explained by the fact that the cultural practices carried out in this district are those of a recession culture and of the lowland. Here, the humidity 
is quite important and it easily favors contamination and development of microorganisms including fungi and especially molds. In fact, low-lying or low-lying wetland crops are generally found in market gardens just at the beginning of the flood, where the various types of waste left by the river such as dead fish and other rotten debris are still there.

These results are in good agreement with those of several authors who show that humidity and temperature are determining factors for the proliferation of microorganisms, including molds with possible production of mycotoxins (Pardo et al., 2005; Hernandez et al., 2008).

The characterization of the local strains of the mold species studied by the present study reveals a contamination of three varieties of chilli pepper (Capsicum chinense, Capsicum annuum, and Capsicum frutescens) produced in Benin by seventy-six (76) fungal species from nine (9) taxonomic genera. The results reveal a variety of fungal agents developing on chillies, thus, affecting its health status and consequently its aesthetics. The genera that were most represented are Aspergillus (34\%), Fusarium (21\%), Penicillium (16\%), Alternaria (7\%), Cladosporium (7\%), Mucor (7\%), Scytalidium (4\%), Trichophyton (3\%), and Rhizopus (1\%). The dominant species in the genus Aspergillus are Aspergillus niger (47\%), Aspergillus flavus (26\%), and Aspergillus ochraceus (16\%). In the genus Fusarium, Fusarium solani (41\%), Fusarium moniliforme (30\%), and Fusarium oxysporum (19\%) are the most frequently isolated. On the other hand, Penicillium was Penicillium expansum (43\%), Penicillium cyclopium (36\%), and Penicillium citrinum (23\%). Specific diversity was higher in the genus Aspergillus (twenty-six different species) followed by the genus Fusarium (sixteen species) and the genus Penicillium (twelve species).

The predominance of telluric genera such as Aspergillus, Penicillium, Fusarium, or Rhizopus with other less common genera such as Cladosporium in spice samples, fresh fruits, and vegetables such as chilli pepper has been reported by several authors (Erdogan, 2004; Kumar, 2008; Houmairi \& Hicham, 2015). Several studies have pointed out that species that affect spices are storage xerophiles such as Aspergillus spp. and Penicillium spp. or preharvest contaminants such as Fusarium (Kachkouch et al., 2012; Houmairi \& Hicham, 2015). They are a group of molds normally confined to the soil but found on spices, fresh fruits, and vegetables under precarious hygienic conditions in relation to harvesting, drying, storage, and transport procedures depending on whether they have undergone or not preventive treatments (Abu Donia, 2008; Kachkouch et al., 2012).

The most contaminated chilli pepper samples would certainly have the highest moisture levels and come from lowland or lowland wetland crops. Also, poor farming practices are an undeniable cause of contamination of the chilli pepper in the open field by molds and, therefore, later by mycotoxins 
once the favorable conditions are met for their production by the latter. These results are in good agreement with those of several authors showing that humidity and temperature are determining factors for the proliferation of microorganisms, including molds, with possible production of mycotoxins of all kinds (Hernandez et al., 2008; Houmairi \& Hicham, 2015). Research conducted by Zinedine (2004) shows the presence of Aflatoxins (B1, B2, G1, and G2) produced by the genera Aspergillus in the powdered chilli peppers analyzed.

Our results are therefore in agreement with those of Zinedine, and it testifies to a possible presence of Aflatoxins on samples of chilli pepper already contaminated with Aspergillus spp. in Benin. However, this relationship is not always obvious because there are intrinsic factors that are the constituents of each species of plant and other extrinsic factors that are the environmental and geographical circumstances that condition the production of mycotoxins (Erdogan, 2004; Zinedine, 2004; Nguyen, 2007; OuattaraSourabié, 2011; Debodé et al., 2016; Meilé, 2017). Indeed, the presence of fungal contaminants and their detrimental effects on the reduction of the yield of production and the sanitary and nutritional quality of chilli peppers is effective. The research carried out by several authors that was reported below confirm this effect of fungal species on plants, spices, grains, oilseeds, and other foods in general.

For example, the Aspergillus genera of which Aspergillus niger causes black crown rot on groundnut (Arachis hypogaea) causes plant mortality (Ezzahiri \& Sekkat 2001; Kachkouch et al., 2012). It attacks apples (Solanum tuberosum) in conservation (Attrassi et al., 2005). In Brazil, Mendes et al. (1998) reported that Aspergillus flavus attacks Musa spp., Rice (Oryza sativa), and coconut (Cocos nucifera). This pathogen can affect several banana species such as Musa textilis in Philippine (Teodoro, 1937) and Musa accuminata in Thailand (Lumyong et al., 2003). Fusarium oxysporum is certainly the most common species of Fusarium in nature (Kachkouch et al., 2012). It is present in the soil all around the whole world where it behaves either as parasite or saprophyte. It has many specialized forms that attack many plant species, such as Cucurbitaceae, asparagus, and ornamentals (Champion, 1997; Kachkouch et al., 2012).

Banana species are Musa sapientum (Alvarez, 1976), Musa paradisiaca (Urtiaga, 1986), Musa accuminata (Lumyong et al., 2003), and pineapple (Ananas comosus) (Mendes et al., 1998) which are the host plants of Penicillium spp.

Alternaria alternata is a very formidable species for a wide range of hosts attacking the foliage, stems, and fruits of its hosts (Kachkouch et al., 2012). The lesions are black, well defined, more or less circular and zoned on the leaves (Bigre et al., 1987). It is considered a saprophyte on cereals but 
Wrather and Sweets (1999) reported that this species causes ear rot (Berber, 2008; Kachkouch et al., 2012).

Recent studies in Benin have revealed the presence of these molds in seeds and groundnut cake (Arachis hypogaea) (Garba et al., 2014), on Maize (Zea mays) (Ba et al., 2016), on millet (Pennisetum glaucum), and on sorghum (Sorghum bicolor) grains (Tovidé et al., 2018). Other studies have also confirmed the presence of molds including Aspergillus flavus in groundnut seeds in Burkina-Faso (Ouattara-Sourabié, 2011) and, very recently, the contamination of smoked and dried fish from Lake Fitri in the Batha region of Chad by fungal strains has also been proven (Abdoullahi et al., 2019). Today, these molds are the most well-known contaminants in chilli peppers and unfortunately deteriorate to its sanitary quality, causing huge economic losses (INRAB, 2009). Generally, contamination evolves after harvest, storage, or storage based on all intrinsic and extrinsic factors (Royer \& Tap 2004; Nguyen, 2007).

It is certain that the present work constitutes a true base for the evaluation of the current state of the chilli peppers produced in Benin. Furthermore, it reveals, for the first time, the presence of nine (9) fungal genera on the varieties of chilli pepper (Capsicum chinense, Capsicum annuum, and Capsicum frutescens) including Alternaria spp., Cladosporium spp., Mucor spp., Scytalidium spp., Trichophyton spp., and Rhizopus spp. in addition to the best-known fungal species of agricultural and food products such as Aspergillus spp., Penicillium spp., and Fusarium spp. Thus, appropriate measures must be taken to improve the sanitary quality of chillies before harvest in order to protect consumers against possible diseases caused by molds and their toxins.

\section{Conclusion}

The present study included two hundred and forty (240) samples of three chilli pepper varieties (Capsicum chinense, Capsicum annuum and Capsicum frutescens) directly from the cultivated fields of six districts of Benin. The results of the analysis showed that the majority of these are of unsatisfactory sanitary quality and have a fairly high average mold load predominantly dominated by several species of the genus Aspergillus (34\%), Fusarium (21\%), Penicillium (16\%), Alternaria (7\%), Cladosporium (7\%), Mucor (7\%), Scytalidium (4\%), Trichophyton (3\%), and a species of the genus Rhizopus (1\%). A total of seventy-six (76) fungal strains were isolated. Indeed, no real study has been done until now on the fungal contamination of chilli peppers produced and consumed in Benin. Thus, it is for the first time that the fungal species Aspergillus spp., Fusarium oxysporum, Penicillium spp., Alternaria alternata, Cladosporium spp., Mucor spp., Scytalidium dimitadium, Trichophyton spp., and Rhizopus spp. were isolated from chilli 
pepper varieties produced in Benin. Since some of these molds produce mycotoxins that can cause serious illness in consumers at certain concentrations, it is necessary to improve the cultural practices and to respect the technical production routes of chilli pepper recommended by the competent structures for the cultivation of chilli pepper as well, in the humid lowlands which is only on the mainland.

\section{Acknowledgment}

We thank the France Campus who through the Service Cooperation and Cultural Action (SCCA) of the Embassy of France provided the financial support we needed for this research.

\section{References:}

1. Abou-Arab, A.A.K., Soliman, A.K., EL Tantawy, M.E., Ismail, B.R., \& Khayria, N. (1999). Estimation quantitative de certains contaminants dans les plantes médicinales d'usage courant sur le marché égyptien. Food Chemistry, 67: 357-363.

2. Abou Donia, M.A. (2008). Métaux lourds dans les épices et les plantes médicinales égyptiennes et effet du traitement sur leur teneur. Global veterinaria, 2(4): 175-181.

3. Alvarez, M.G. (1976). Catalogue de projets d'enquêtes de plantes mexicaines. Fitofilo, 71 : 1-169.

4. Association Française des Enseignants de Parasitologie et Mycologie (ANOFEL). (2014) : Aspergilloses et autres champignons filamenteux opportunistes. 1-19 pp.

5. Attrassi, K., Selmaoui, K., Ouazzani-touhami, A., Badoc, A. \& Douira, A. (2005). Biologie et physiologie des principaux agents fongiques de la pourriture des pommes en conservation et lutte chimique par l'azoxystrobine. Bull. Soc. Pharm. Bordeaux, 144: 47-62.

6. Ba, R., Monteiro, N.M.F., Hounguè, U., Donou Hounsodé, M.T., Gbaguidi, F. \& Baba-Moussa, L. 2016. Perception des producteurs et impact des facteurs socio-économiques sur la connaissance des mycotoxines du maïs en stockage au Bénin. Int. J. Biol. Chem. Sci. 10(1): 155-166.

7. Bae, H., Jayaprakasha, G.K., Jifon, J. \& Patil, B.S. (2012). Variation of antioxidant activity and the levels of bioactive compounds in lipophilic and hydrophilic extracts from hot pepper (Capsicum spp.) cultivars. Food Chemistry, 134: 1912-1918.

8. Berber, F., Ouazzani-Touhami, A. \& Douira, A. (2008). Identification de la mycoflore pathogène de Sorghum bicolor (L.) Moench, cultivé dans le Gharb et le Loukkos (Nord-ouest du Maroc). Bulletin de l'Institut Scientifique, Rabat. Section Sciences de la Vie, 30: 2-18. 
9. Bigre, JP., Morand, JC. \& Tharaud, M. (1987). Pathologie des cultures florales et ornementales. Ed. Lavoisier, Paris, 233 pp.

10. Centre québécois d'inspection des aliments et de santé animale (CQIASA). (2009). Méthodes analytiques accréditées selon ISO/CEI 17025 par le Conseil canadien des normes, 131: 1-59.

11. Campbell, C. K., Johnson, E. M., Warnock, D. W. (2013). Identification of pathogenic fungi. Health Protection Agency. WileyBlackwell, seconde édition. Hong Kong.1-337 pp.

12. Champion, R. (1997). Identifier les champignons transmis par les semences. INRA, Paris, 398 pp.

13. Chabasse, D., Bouchara, J.P., Gentile, L., Brun, S., Cimon, B., \& Penn, P. (2002). Les moisissures d'intérêt médical. (edn) Bioforma. Paris. $160 \mathrm{pp}$.

14. Compaore, H., Sawadogo-Lingani, H., Samandoulougou, S., Guira, F., Savadogo A., \& Traore A. S. (2017). Aptitude de trois souches de moisissures à produire des enzymes extracellulaires en milieu solide au Burkina Faso. Journal of Applied Biosciences, 110 : 10776-10782.

15. Cooney, D. G. \& Emerson, R. (1964). Champignons thermophiles. 1188pp.

16. Debode, F., Lateur, M., Van Damme, J. \& CRA, W. (2016). Les mycotoxines. Dossier spécial : Conservation des fruits et légumes. Itinéraires BIO, 30: 30-32.

17. Dufresne, P. \& St-Germain, G. (2018). Identification des champignons d'importance médicale. Institut National de santé publique. Québec. 164 pp.

18. Erdogan, A. (2004). The aflatoxin contamination of some pepper types sold in Tur-key. Chemosphere, 56: 321-325.

19. Ezzahiri, B. \& Sekkat, A. (2001). Maladies et ravageurs de l'arachide identification et moyens de lutte. Bulletin Mensuel d'Information et de Liaison du PNTTA. Transfert de Technologie en Agriculture, 86: 1-4.

20. FAO (2016). FAOSTAT Database. Food and Agriculture Organization, Roma, Italy. Available online at URL: www.fao.org.

21. FAO/OMS (2007). Programme mixte FAO/OMS sur les normes alimentaires, Commission du Codex Alimentarius. Céréales, légumes secs, légumineuses et matières protéiques végétales, $1^{\text {ère }}$ édition, Rome, Italie. $128 \mathrm{pp}$.

22. Fondio, L, N'zi, J.C. \& Kobenan, K. (2015). Comportement agronomique et sanitaire de nouvelles lignées de piment (Capsicum sp) dans le Sud de la Côte d'Ivoire. Journal of Applied Biosciences, 92: 8594-8609. 
23. Garba, K., Adeoti, K., Hodonou, A., Tidjani, A., Hounhouigan, J. \& Toukourou, F. (2014). Study of Sanitary of Groundnut Oil and Peanut Cakes from Agonlin Plateau: Identification of Critical Control Points During Groundnut Craft Transformation. Microbiologie Hygiène Alimentaire, 75: 17-21.

24. Hernandez, J.M., Garcia, R.J., Rodriguez, P., \& Toruño, I.V. (2008). Analytical method development and monitoring of Aflatoxin B1, B2, G1, G2 and Ochratoxin A in animal feed using HPLC with Fluorescence detector and photochemical reaction device. Journal of Agricultural and Food Chemistry, 56: 751-756.

25. Houmairi, H. \& Hicham, M. (2015). Composition en mycobiota et mycotoxines de type aflatoxines et ochratoxine A de quelques épices dans la région centrale du Maroc. J. Mater. Environ. Sci. 6(3): 877884.

26. INRAB (2009). Référentiel technico-économique de la production agricole. Production durable du piment au bénin. Institut National des Recherches Agricoles du Bénin, Abomey-Calavi, République du Bénin. 47pp.

27. Kachkouch, W., Ouazzani-Touhami, A., Benkirane, R., \& Douira, A. (2012). Identification de la mycoflore de l'espece ornementale, erythrina caffra, au maroc. Rev. Ivoir. Sci. Technol, 19: 88 - 101.

28. Koffi, A.C., Koffi-Nevry, R., Kouassi, K.C., \& Loukou, Y. G. (2014). Activité des extraits de six variétés de piment (Capsicum) utilisés en Côte d'Ivoire. Journal of Applied Biosciences, 82:7379 - 7388.

29. Kumar, V., Basu, M.S., \& Rajendran, T.P. (2008). Implication de la contamination par les aflatoxines dans les produits agricoles. Crop Protection, 27: 891-950.

30. Lecellier, A. (2013). Caractérisation et identification des champignons filamenteux par spectroscopie vibrationnelle. Thèse de Doctorat. Reims, France, 1-196 pp.

31. Lejeune, M.P.G.M., Kovacs, E.M.R., \& Westesterps-Plantenga, M.S. (2003). Effect of capsaicin on substrate oxidation and weight maintenance after modest body weight loss in human subjects. Cambridge Journals of Nutrition, 90: 651-659.

32. Lumyong, P., Photita, W., McKenzie, E.H.C., Hyde, K.D. \& Lumyong, S. (2003). Saprobic fungi on dead wild banana. Mycotaxon, 85: 345-346.

33. Mendes, M.A.S., da-Silva, V.L. \& Dianese, J.C. (1998). Fungos em Plants no Brasil. Embrapa-SPI/Embrapa-Cenargen, Brasilia, 555 pp.

34. Meile, J.C. (2017). Risques et enjeux associés à la présence de mycotoxines sur les cultures et aliments de l'Océan Indien. UMR 
Qualisud - CIRAD Réunion, Journées Qualireg, Montpellier, France. 24pp.

35. Nguyen, M.T. (2007). Identification des espèces de moisissures potentiellement productrices de mycotoxine dans le riz commercialisé dans cinq provinces de la région centrale de Vietman-Etude des conditions pouvant induire la production de mycotoxines. Thèse de doctorat, Toulouse, France. 147pp.

36. Orobiyi, A. (2015). Etude ethnobotanique, evaluation participative et caracterisations agromorphologique et biochimique du piment (Capsicum annuum L.) au Bénin. Thèse de doctorat. Abomey-Calavi, République du Bénin. 119pp.

37. Ouattara-Sourabié, P.B. (2011). Contribution à la conservation des récoltes : Cas de l'inhibition de la croissance et de la production d'aflatoxine chez Aspergillus spp. par des extraits de plantes. Thèse de Doctorat. Ouagadougou, Burkina-Faso. 1-135 pp.

38. Pardo, E., Marin, S., Ramosm, A.J., \& Sanchis, V. (2005). Conditions de formation de l'ochratoxine A lors du séchage, du transport et de différentes marchandises. Journal of food protection, 68: 133-138.

39. Pitt, J.I. \& Hocking, A.D. (1985). Interfaces entre genres apparentés à Aspergillus et Penicillium. Mycologia, 77 (5): 810-824.

40. Raper, K.B. \& Fennell, D.I. (1965). Le genre Aspergillus. Williams et Wilkins, Philadelphie, 686 pp.

41. Royer, G. \& TAP, J. (2004). Les mycotoxines. Université Paris XII Année 2003/2004 Institut Universitaire Professionnalisé. Salon International de l'Alimentation (SIAL), Paris, France. 7 pp.

42. Teodoro, N.G. (1937). An enumeration of Philippine fungi. Techn. Bull. Dept. Agric. Comm. Manila, 4-585 pp.

43. Tilahun, S., Paramaguru, P., \& Rajamani, K. (2013). Capsaicin and ascorbic acid variability in chilli and paprika cultivars as revealed by HPLC analysis. J. Plant Breed. Genet, 1(2): 85-89.

44. Toffa, D. D. (2015). Étude de la contamination de certains aliments d'origine végétale de la République du Niger les moisissures toxinogènes. Thèse de Doctorat. Niamey, Niger, 1-252 pp.

45. Tovide, N., Adéoti, K., Noumavo, P. A., Garba, K., Ohin, B., Soninhekpon, A., Tchobo, F., Gandonou, C., Toukourou, F. \& BabaMoussa, F. (2018). Occurrence of Molds and Identification of Mycoflora Contaminating Millet and Sorghum Produced and Consumed in Benin. International Journal of Current Microbiology and Applied Sciences, 7(8): 2319-7706.

46. Tozlovanu, M. (2008). Evaluation du risque de contamination alimentaire en mycotoxines néphrotoxiques et cancérogènes 
(notamment l'ochratoxine A) : Validation de biomarqueurs d'exposition et d'effet. Thèse de Doctorat. Toulouse, France.1-261 pp. 47. Urtiaga, R. (1986). Indice de enfermedades en plantas de Venezuela y Cuba. Impresos en Impresos Nuevo Siglo. S.R.L., Barquisimeto, Venezuela, $202 \mathrm{pp}$.

48. Wrather, A. \& Sweets, L. (1999). Management of grain sorghum diseases in Missouri.,4 pp.

49. Zinedine, A. (2004). Détermination des mycotoxines dans les aliments et étude de la réduction des aflatoxines par les bactéries lactiques isolées des ferments panaires traditionnels. Thèse de doctorat, Maroc. $120 \mathrm{pp}$. 